\title{
PEMBERDAYAAN EKONOMI MASYARAKAT PESISIR DANAU LIMBOTO MELALUI PENGOLAHAN IKAN NILA (OREOCHROMIS NILOTICUS) MENJADI PRODUK UNGGULAN KKN-PPM
}

\author{
Dewa Gede Eka Setiawan ${ }^{1}$, Sri Nuryatin Hamzah ${ }^{2}$ \\ Program Study Fisika ${ }^{1}$, Program Study Manajemen Sumberdaya Perairan ${ }^{2}$ \\ Fakultas Matematika dan IPA Universitas Negeri Gorontalo', Fakultas Perikanan Dan Ilmu Kelautan \\ Universitas Negeri Gorontalo ${ }^{2}$, \\ Penulis Korespondensi : email: dewagedeekas@ung.ac.id
}

\begin{abstract}
Abstrak
Implementasi program pemberdayaan masyarakat melalui pengolahan Ikan Nila melalui kegiatan KKN PPM tahun 2020 dilaksanakan di desa Iluta. Tujuan dari program ini adalah meningkatkan nilai ekonomi komoditas ikan nila di Desa Iluta, Kecamatan Batudaa, Kabupaten Gorontalo, yang di nilai masih terkendala dalam proses distribusi/penjualan. Upaya yang di lakukan adalah melalui pengolahan bahan baku ikan nila menjadi produk olahan yang enak dan bergizi, serta memiliki nilai jual yang berkompoten di seluruh kalangan masyarakat. Adapun metode yang di gunakan dalam program ini adalah penyuluhan dan pelatihan. Program ini di dukung langsung oleh aparatur pemerintah Desa Iluta, yang di pimpin langsung oleh Kepala Desa Iluta selaku mitra dalam program ini. Alur kegiatan meliputi tahap persiapan berupa observasi ke dinas / instansi terkait dan pembekalan Mahasiswa KKN-PPM. Kemudian tahap pelaksanaan, yaitu penyuluhan dan pelatihan pada masyarakat di dusun yakni Dusun I Parungi, Dusun II Bulalo, Dusun III Olibuw, yang berpusat di Kelompok Usaha Bersama (KUBE) FAKIR MISKIN Desa Iluta. Dengan adanya partisipasi langsung oleh masyarakat, diharapkan muncul ide-ide baru dan kreatif oleh masyarakat dalam mengolah ikan nila. Sehingga program ini dapat berkelanjutan.
\end{abstract}

Kata Kunci : Pemberdayaan, pengolahan, ikan nila

\begin{abstract}
The implementation of a community empowerment program through Nile Tilapia processing at KKN PPM (Community Service - Community Empowerment Learning Program) activity in 2020 took place in Iluta village. The goal of this program was to improve the economic value of Nile Tilapia commodity in Iluta Village, Batudaa Sub-district, Gorontalo District, which was still hampered by distribution/sales process. The effort to deal with the issue was through the processing of Nile Tilapia raw material to be a tasty and nutritious processed product and had a competent selling price in the entire community. The methods used in this research were counseling and training. The program was supported by the apparatus of Iluta Village Government directly and led by Head of the Village as a partner in this program. The step of activity encompassed preparation stage in the form of observation to the related agency/ institution and training for KKN PPM students. In addition, the implementation stage meant conducting counseling and training to the community in a hamlet, namely hamlet I Parungi, hamlet II Bulalo, and hamlet III Olibuw which was centered on Kelompok Usaha Bersama (KUBE or Collective Enterprise Group) FAKIR MISKIN. The direct participation of the community was expected to come up with new and creative ideas in processing the Nile Tilapia. Therefore, the program could be sustainable.
\end{abstract}

Keywords: Empowerment, processing, Nile Tilapia

\section{PENDAHULUAN}

Ikan merupakan sumber bahan pangan yang bermutu tinggi terutama karena ikan banyak mengandung protein, lemak, vitamin dan mineral yang sanggat dibutuhkan oleh manusia (Harnisah : 2018)). Produksi perikanan budidaya ikan nila mengalami peningkatan tiap tahunnya (Novia : 2016). Ikan nila merupakan jenis ikan air tawar yang hampir menyerupai ikan mas, ikan nilai ini berasal dari Afrika bagian timur di perairan sungai Nil, danau Tangiya Nigeria. Jenis ikan ini pada awal perkembangan termasuk kedalam kelompok Tilapia ( Saratharaodon nilaticu ). Ikan nila masuk kedalam famili Cichilidae dengan ordo percomorphi yang memiliki tulang belakang.
Ikan nila termasuk komoditas yang banyak dikembangkan dikarenakan permintaan pasar yang cukup tinggi, rasa dagingnya yang enak, harga yang relatif stabil serta pemeliharaannya yang mudah (Diah : 2018). Selain itu, ikan nila memiliki bentuk pipih, punggung tinggi, pada bagian badan dan sirip ekor di temukan garis lurus ( vertikal ) serta juga mempunyai sirip punggung ditemukan garis lurus memanjang. Ikan nila dapat di morfologikan berdasarkan bentuk fisiologis yaitu memiliki bentuk tubuh bulat pipih, pungung agak tinggi, badan, sirip ekor dan sirip punggung terdapat garis lurus memanjang. Ikan ini memiliki lima buah sirip yaitu sirip punggung, sirip data, 
sirip perut, sirip anal dan sirip ekor. Dengan adanya sirip tersebut sangat membantu pergerakan ikan nila semakin cepat di perairan air tawar.

Menurut Pratama (2009), ikan nila mempunyai nilai bentuk tubuh yang pipih kea rah vertical (kompres) dengan profil empat persegi panjang kea rah anteroposterior, posisi mulut terletak di ujung/termal. Pada sirip ekor tampak jelas garis-garis yang vertical dan pada sirip punggungnya garis terlihat condong lekuknya. Ciri ikan nila adalah garis-garis vertikal berwarna hitam pada sirip, ekor, punggung dan dubur. Pada bagian sirip caudal/ ekor yang berbentuk membulat warna merah dan biasa digunakan sebagai indikasi kematangan gonad (Pratama, 2009).

Kandungan protein ikan nila sebesar $43,76 \%$; lemak $7,01 \%$, kadar abu $6,80 \%$ per 100 gram berat ikan, sedangkan ikan lele memiliki kandungan protein $40,28 \%$, lemak $11,28 \%$, dan kadar abu 5,52 (Imanawati, 2000). Hasil penelitian Ramlah dkk (2016) menunjukkan dalam 100 gram ikan nila mempunyai kandungan protein 16,79 g, kandungan karbohidrat 0,32 g, kandungan lemak 0,18 g, kandungan kalsium 4,782 mg, kandungan fosfor $610 \mathrm{mg}$, dan kandungan zat besi $0,835 \mathrm{mg}$ (Ramlah : 2016). Keunggulan ikan nila : 1) Pertumbuhan lebih cepat dan mudah dikembangbiakan, 2) Dapat dilakukan pemijahan setelah umur 5-6 bulan, 3) Setelah $1-1,5$ bulan, dapat dipijah kembali, 4) Mempunyai keturunan jantan dominan, 5) Nilai ekonomis relatif jauh lebih tinggi, 6) Bagian tubuh dapat dimanfaatkan dibeberapa bidang. Ikan nila merupakan salah satu ikan yang kaya akan kandungan nutrisi yang di butuhkan oleh tubuh kita, selain itu ikan nila juga bermanfaat untuk menjaga tubuh kita tetap sehat. Dengan berbagai cara ikan nila di olah untuk di konsumsi harian, di Jepang di kenal makanan sushi dengan bahan ikan salmon dan tuna segar, Tapi di sushi yang terkenal di indonesia adalah ikan nila simak selengkapnya pada table 1 berikut.

\begin{tabular}{|c|l|l|}
\hline No & \multicolumn{1}{|c|}{ Kandungan gizi } & \multicolumn{1}{|c|}{ Kadar } \\
\hline 1 & Kalori (kal) & 128 \\
\hline 2 & Total lemak $(\mathrm{mg})$ & 3 \\
\hline 3 & Lemak jenuh $(\mathrm{mg})$ & 1 \\
\hline 4 & Lemak tak jenuh $(\mathrm{mg})$ & 2 \\
\hline 5 & Vinamin B12 $(\mathrm{mg})$ & 1.86 \\
\hline 6 & Kolestrol $(\mathrm{mg})$ & 57 \\
\hline 7 & Fosfor $(\mathrm{mg})$ & 204.00 \\
\hline 8 & Selenium $(\mathrm{mcg})$ & 54.40 \\
\hline 9 & Protein $(\mathrm{mg})$ & 26 \\
\hline 10 & Niacin $(\mathrm{mg})$ & 4.74 \\
\hline 11 & Kalium $(\mathrm{mg})$ & 380 \\
\hline
\end{tabular}

Sumber : Laboratorium Perikanan Tahun 2020

Berikut Adalah Manfaat ikan nila : 1) Dalam ikan nila kandungan lemak yang rendah, sehingga tidak meningkatkan kadar kolesterol, 2) Ikan Nila juga di kenal rendah kalori dan karbohidrat jadi sangat pas untuk program diet sehat, 3) Kandungan omega 6 yang ada dalam ikan nila bermanfaat mencegah dermatitis, 4) Kandungan fosfor yang ada dalam ikan nila sangat bermanfaat untuk pembentukan tulang dan gigi, 5) Selenium yang ada dlam daging ikan nila bemanfaat untuk mencegah kanker, serangan jantung dan katarak, 6) Kandungan vitamin b 12, bermanfaat untuk membentuk sel darah merah, 7) Mengandung potassium yang berguna untuk mencegah pembentukan batu ginjal dan melancarkan aliran oksigen ke otak, 8) Kandungan kolagen yang jumlahnya lebih rendah daripada daging ternak. Sehingga membuat tekstur daging ikan menjadi lebih empuk dan mudah dicerna, 9) Mencegah Kanker Prostat.

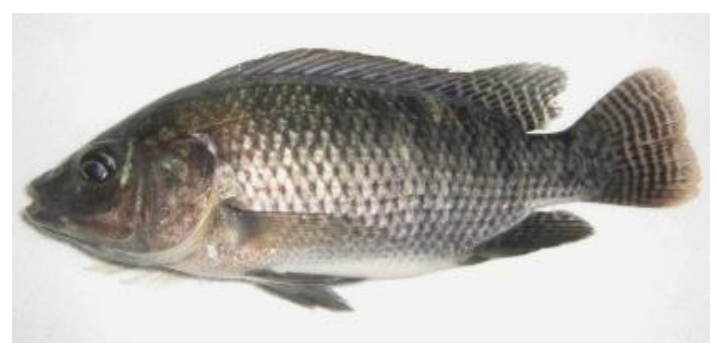

Gambar 1. Hasil Panen Ikan Nila Desa Iluta

Seiring perkembangan zaman, produk olahan ikan tidak lagi berbentuk ikan utuh, melainkan dapat diolah menjadi berbagai macam bentuk olahan yang akan berpengaruh terhadap tingkat konsumsi masyarakat terhadap ikan (Sugih:2017). Oleh karena itu pengolahan bahan baku ikan menjadi produk sangat dibutuhkan untuk meningkatkan ekonomi kelompok. Adapun kelompok sasaran dalam kegiatan ini adalah masyarakat nelayan pembudidaya Ikan Nila dan kelompok pembuat kue di Desa Iluta. Melalui Observasi lapangan, rata-rata Masyarakat nelayan pembudidaya Ikan Nila memiliki kondisi perekonomian yang tergolong cukup rendah. Oleh karena itu tujuan kegiatan ini adalah melaksanakan penerapan iptek pengolahan bahan baku ikan nila menjadi produk bakso. Kelompok sasaran adalah kelompok usaha bersama (KUBE) Fakir Miskin Desa Iluta. Melalui kegiatan ini, diharapkan dapat mendongkrak ekonomi Masyarakat nelayan melalui pengolahan Ikan Nila menjadi produk Bakso yang akan dipasarkan baik melalui pasar tradisional maupun toko-toko yang berada di provinsi Gorontalo.

\section{BAHAN DAN METODE}

Alur pelaksanaan kegiatan dapat dilihat seperti pada diagram dibawah ini : 
Koordinasi Tim, dengan Dinas Instansi terkait dan Pemerintah dan Kelompok

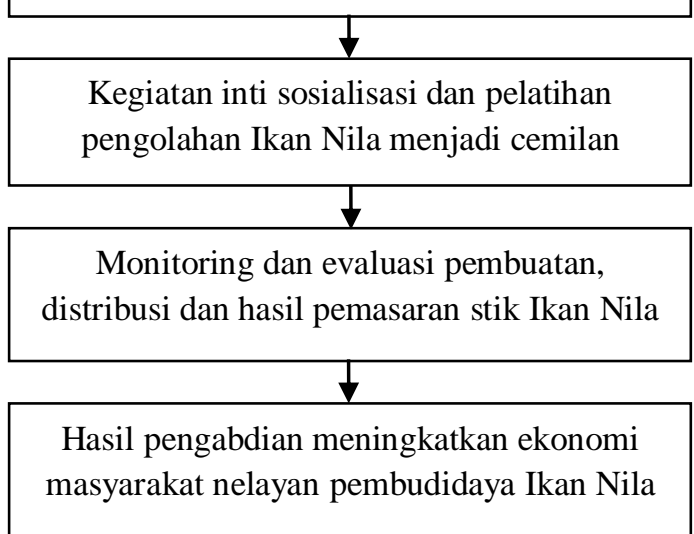

Gambar 2. Alur pelaksanaan Program KKN PPM Desa Iluta 2020

Bentuk program yang dilaksanakan adalah program produksi/pengolaan produk Ikan Nila Higienis.

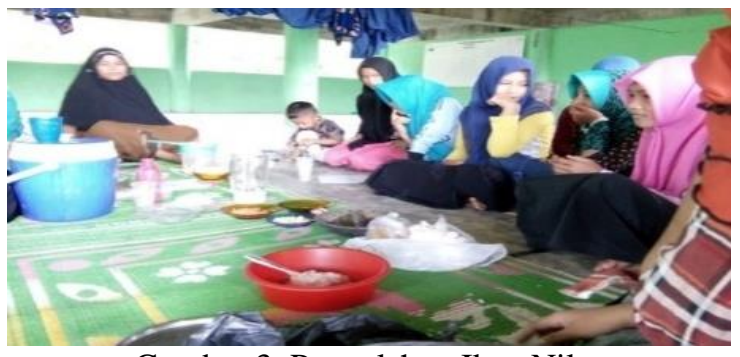

Gambar 3. Pengolahan Ikan Nila

$\begin{array}{cccc}\begin{array}{c}\text { Metode } \\ \text { pemberdayaan }\end{array} & \begin{array}{c}\text { yang } \\ \text { kelompok }\end{array} & \begin{array}{r}\text { digunakan } \\ \text { sasaran }\end{array} & \text { dalam } \\ \text { adalah }\end{array}$ pembelajaran teknik membuat Stik Ikan Nila yang berkualitas disertai teori dan praktek langsung. Pembelajaran disertai praktek akan dilakukan oleh mahasiswa bersama-sama dengan kelompok sasaran yang juga didampingi oleh mitra yang professional di bidangnya.

Prosedur Kerja : 1) Masukkan bahan bakso kedalam baskom. Uleni dengan tangan kosong atau menggunakan bantuan alat pencampur, seperti food processor, 2) Haluskan daging ikan nila sekaligus bahan-bahannya sampai benar-benar hancur, halus dan tercampur rata. 3) Jika bahan adonan susah dibentuk maka tambahkan es batu agar mudah dicetak. 4) Didihkan air dalam panci besar sampai panas. 5) Ambil bahan adonan kemudian genggam adonan bakso. 6) Ambil adonan yang telah keluar dengan bantuan sendok, lalu masukan pada panci air yang telah kita siapkan. 7) Selanjutnya masak pentol atau bola-bola bakso yang Anda buat dengan bantuan panci yang telah kita didihkan dengan api besar.

Metode yang di gunakan yaitu metode observasi partisifasif terhadap objek di mana penulis mengamati dan terlibat langsung dalam setiap langkah kerjanya. Di samping itu di lakukan wawancara dengan pembimbing lapangan serta karyawan yang bekerja di lokasi pengamatan.

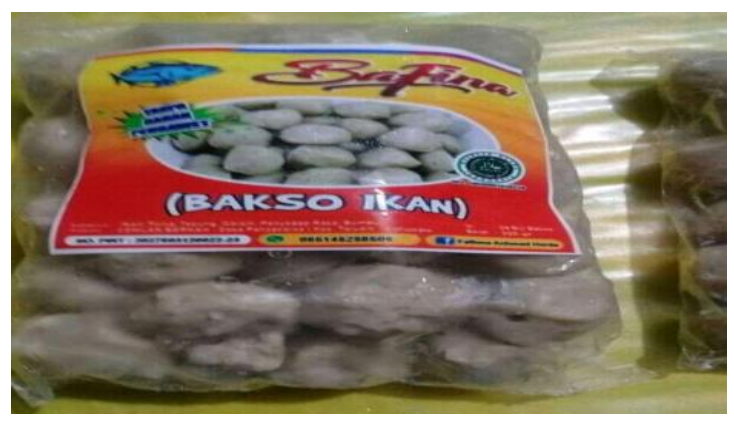

Gambar 5. Hasil Olahan Ikan Nila

\section{HASIL DAN PEMBAHASAN}

Kegiatan bimbingan teknis pengolahan Ikan Nila menjadi ragam produk cemilan yang sehat dan higienis telah dilaksanakan di desa Iluta. Secara rinci luaran yang dihasilkan adalah:

Dalam implementasi program KKN PPM Didesa Iluta pada bulan April dan Mei Tahun 2020, maka hasil yang dicapai dapat dirinci sebagai berikut :

1. Melaksanakan kegiatan pemberdayaan masyarakat kelompok kelompok pengolah ikan nila dalam pengolahan hasil budidaya perikanan menjadi produk bakso yang sehat dan higienis serta bernilai ekonomi yang tinggi.

2. Meningkatnya pengetahuan dan pemahaman kelompok masyarakat pengolah ikan nila dalam pengolahan bahan baku sampai pemasaran sebagai salah satu upaya meningkatkan kesejahteraan.

3. Melaksanakan kegiatan bimbingan teknis pengolahan bahan baku ikan nila mulai tahapan pemilihan bahan baku, pengolahan, manajemen dan sampai pada kegiatan pemasaran.

4. Melaksanakan kegiatan pemasaran produk bakso disekitar lokasi pelaksanaan KKN PPM dan untuk memenuhi pasar lokal.

Melaksanakan kegiatan pemasaran pada mitra program KKN PPM Desa Iluta.

Ikan Nila adalah salah satu komoditas utama yang banyak tumbuh dan dibudidayakan oleh kelompok masyarakat di desa Iluta Kecamatan Batudaa Kabupaten Gorontalo. Melimpahnya sumberbahan baku ini merupakan satu pelung yang menjanjikan dalam kegiatan bisnis pengolahan makanan bakso dengan bahan baku ikan nila. Untuk meningkatkan nilai tambah tersebut maka program KKN PPM Desa Iluta tahun 2020 ini dilaksanakan pada bulan April dan Mei dengan manfaat yang diperoleh sebagai berikut :

1. Memberdayakan ekonomi kelompok masyarakat kelompok nelayan dan pengolah ikan nila sebagai bakso. 
2. Memberikan pengetahuan kewirausahaan dalam pengolahan bakso menjadi produk makanan tambahan yang sehat dan higienis.

3. Menciptakan nilai tambah bagi produk bakso berbahan dasar ikan nila sebagai upaya meningkatkan kesejahteraan ekonomi bagi masyarakat/nelayan pembudidaya dan pengolah di desa Iluta.

4. Memberikan pengetahuan dan pengalaman empirik baik bagi kelompok masyarakat maupun bagi mahasiswa dalam pengolahan hasil perikanan budidaya nila menjadi produk Bakso yang memiliki nilai ekonomi tinggi.

5. Mengidentifikasi masalah dan potensi unggulan desa, serta mengaplikasikan ilmu pengetahuan dan teknologi di lingkungan masyarakat untuk menyelesaikan masalah yang berkembang di desa untuk diolah menjadi potensi nyata untuk pemberdayaan dan kesejahteraan masyarakat.

Pentingnya pengolahan hasil perikanan Nila karena komoditas ini memiliki kandungan gizi yang tinggi dan baik bagi manusia. Pengolahan ikan nila secara higienis akan dapat meningkatkan nilai tambah produk ini secara ekonomi.

Berbagai kelebihan ikan nila dan hasil pengolahannya yang memberikan manfaat telah menjadi fokus utama program KKN PPM melalui pengembangan dan pengolahan ikan nila pada kelompok masyarakat di desa Iluta Kecamatan Batudaa Kabupaten Gorontalo. Selanjutnya untuk menguatkan dan mengembangkan kapasitas pengolahan ikan nila maka melalui kegiatan inti program KKN PPM di desa ini dilaksanakan dengan kegiatan Bimbingan Teknis bagi kelompok pengrajin dalam pengolahan ikan nila menjadi bakso. Bimbingan teknis ini meliputi segala aspek penting dalam manajemen usaha pengolahan ikan nila menjadi bakso.

Faktor yang menghambat dalam implementasi KKN PPM Desa Iluta tahun 2020 adalah sebagai berikut :

1. Situasi pandemic covid 19 yang berakibat pada pembatasan social dan pembatasan aktifitas kelompok dan masyarakat secara umum.

2. Mulai menurunnya bahan baku sebagai akitbat dari pembatasan social masyarakat di pedesaan, khususnya desa Iluta.

3. Terbatasnya ruang lingkup dan aktifitas pemasaran produk sebagai akibat dari pandemic covid 19 yang secara perlahan telah merubah pola konsumsi masyarakat.

Adapun factor pendukung selama pelaksanaan program KKN PPM Desa Iluta tahun 2020 dapat dirinci sebagai berikut :

1. Dukungan kelompok masyarakat pengolah untuk terus bertahan dan berupaya melakukan produksi walaupun ditengah kondisi pembatasan social.
2. Kesadaran kelompok masyarakat untuk mengikuti prosedur covid 19, sehingga aktifitas kelompok dalam produksi tetap bertahan.

3. Dukungan pemerintah desa untuk kelompok masyarakat untuk tetap berproduksi dan akan berupaya memberikan bantuan stimulus melalui pemberdayaan ekonomi usaha masyarakat.

Capaian hasil implementasi program $\mathrm{KKN}$ PPM di desa Iluta telah menunjukkan manfaat bagi kemampuan dan pengalaman kelompok sasaran dalam upaya meningkatkan kuantitas dan kualitas produk olahan ikan nila. Hasil ini telah mampu meningkatkan nilai ekonomi ikan nila dari bahan mentah menjadi produk bakso yang bernilai ekonomi untuk meningkatkan kesejahteraan kelompok sebagai sasaran. Untuk itu rencana tahap selanjutnya direncanakan dengan kegiatan penguatan meliputi:

1. Penguatan manajemen tingkat lanjutan untuk meningkatkan kuantitas dan kualitas produksi olahan ikan nila menjadi bakso.

2. Diversifikasi produk berbahan baku ikan nila dengan menambah jumlah produk hasil olahan

3. Pemanfaatan peluang akses permodalan dan peluang pasar di tingkat local untuk menningkatkan hasil penjualan

Hasil kegiatan bimbingan teknis proses pembuatan cemilan Ikan Nila menjadi ragam produk yang sehat dan higienis di Desa Iluta memberikan pengalaman dan penguatan terhadap anggota kelompok pengrajin akan besarnya potensi bisnis produk cemilan Ikan Nila. Disamping itu pula bimbingan teknis memberikan bekal pengetahuan manajemen pengolahan usaha beserta implementasinya pada kegiatan usaha. Hal penting lainnya dari bimbingan teknis adalah pengetahuan bagi kelompok usaha juga diberikan mengenai aspek hukum dalam usaha. Hal tersebut untuk memberikan jaminan kepastian hukum maupun legalitas terhadap usaha yang dijalankan, juga untuk memberikan pengetahuan tentang berbagai resiko yang mungkin saja terjadi dalam bisnis. Disamping itu pula peserta sebagai kelompok sasaran dibekali tentang kemitraan dengan pihak usaha lain, perencanaan pasar dan sebagainya. Kegiatan bimbingan teknis dilanjutkan pula dengan teori dan praktek penyusunan rencana binis bagi sektor usaha kecil menengah yang diikuti oleh seluruh peserta anggota kelompok.

\section{KESIMPULAN}

Berdasarkan implementasi program KKN PPM Di desa Iluta Tahun 2020 dengan tema Pemberdayaan Ekonomi Masyarakat Pesisir Danau Limboto Melalui Pengolahan Ikan Nila menjadi produk unggulan KKN PPM. Program ini telah memberikan hasil yang sangat bermanfaat bagi kelompok sasaran, diantaranya adalah : 
1. Meningkatnya pemahaman kelompok masyarakat nelayan dan pengolahan bahan baku ikan nila menjadi produk bakso yang bernilai ekonomi sebagai salah satu upaya meningkatkan kesejahteraan.

2. Tumbuhnya kemandirian kelompok dalam pengolahan ikan nila menjadi produk bakso yang sehat dan higienis.

3. Meningkatnya pendapatan kelompok masyarakat sasaran sebagai hasil dari penjualan produk bakso ikan nila yang telah memiliki konsumen tetap sesuai mitra dalam program kerja KKN PPM.

4. Meningkatnya produktivitas kelompok masyarakat sebagai sasaran program, dalam pemanfaatan sumber bahan baku ikan nila yang melimpah di pesisir danau limboto.

5. Adanya keberlanjutan Produktivitas kelompok masyarakat atas produksi bakso ikan nila yang sehat, higienis dan memiliki nilai ekonomi tinggi sesuai permintaan pasar.

\subsection{Saran}

Berdasarkan hasil capaian dan simpulan di atas maka dapat disampaikan beberapa saran sebagai berikut :

1. Melimpahnya hasil budidaya perikanan juga dialami desa sekitar, oleh karena itu disarakan desa tetangga juga dapat mengikuti model program yang telah dilaksanakan di desa Iluta untuk meningkatkan pemberdayaan ekonomi kelompok sasaran.

2. Hasil capaian yang telah diperoleh kelompok sasaran disarakan untuk dapat terus ditindaklanjuti/ditingkatkan pada waktu yang akan datang, sebagai salah satu upaya meningkatkan kesejahteraan masyarakat.

3. Untuk lebih mengefektifkan produktivitas kelompok masyarakat pengolah bahan baku ikan nila menjadi bakso maka disarankan untuk bermitra dengan kelompok bisnis lainnya untuk meningkatkan produksi, higienis produk sampai pada pemasaran produk pada skala yang lebih luas.

\section{Ucapan Terimakasih}

Setelah melalui berbagai tahapan proses kegiaan KKN-PPM Tahun 2019 maka hasil kegiatan ini telah memberikan manfaat bagi kelompok nelayan dan kelompok ibu-ibu sebagai sasaran. Disamping itu pula manfaat bagi pemerintah Desa, mahasiswa, dosen dan perguruan tinggi. Oleh karena itu pada kesempatan ini kami menyampaikan ucapan terimakasih disampaikan kepada 1) Direktorat jenderal pengabdian masyarakat Kementerian Ristek dan Dikti Republik Indonesia, 2) Pimpinan dan seluruh staf Lembaga Penelitian dan Pengabdian masyarakat Universitas Negeri Gorontalo, 3) Pemerintah Kabupaten Gorontalo, Kecamatan Batudaa Pantai dan pemerintah desa Iluta, 4) Kelompok Nelayan Ikan Nila dan Ibu-ibu kelompok pengolah ragam produk cemilan Desa
Iluta, 5) Tim pelaksana dan mahasiswa peserta KKN-PPM. Semoga hasil kegiatan pengadian ini mampu memberikan manfaat jangka panjang bagi kelompok nelayan dan pengolah Ikan Nila serta masyarakat sekitarnya.

\section{DAFTAR PUSTAKA}

Imanawati H. 2000. Mempelajari tabletasi konsentrat protein ikan dari ikan nila (Oreochromis niloticus). [skripsi]. Bogor: Fakultas Perikanan dan Ilmu Kelautan. Institut Pertanian Bogor.

Diah Asta Putri1, Ambar Pratiwi2, Nurul Suwartiningsih3, Pemberdayaan Kelompok Wanita Tani Dalam Diversifikasi Olahan Ikan Nila, Jurnal Pemberdayaan: Publikasi Hasil Pengabdian kepada Masyarakat Vol. 2, No. 2, Agustus 2018, Hal. 375-380 ISSN: 2088 4559;

Pratama, 2009. Morfologi Ikan Nila. Airlangga. Jakarta. PT Agromedia Pustaka.Jakarta Selatan.

Novia Anggraen*, Yudhomenggolo Sastro Darmanto, Putut Har Riyad, Pemanfaatan Nanokalsium Tulang Ikan Nila (Oreochromis niloticus) pada Beras Analog dari Berbagai Macam Ubi Jalar (Ipomoea batatas L.), Jurnal Aplikasi Teknologi Pangan 5 (4) 2016 CIndonesian Food Technologists

https://doi.org/10.17728/jatp.187

Ramlah, Eddy S., dan Zohrah H. (2016) Perbandingan Kandungan Gizi Ikan Nila Oreochromis niloticus Asal Danau Mawang Kabupaten Gowa Dan Danau Universitas Hasanuddin Kota Makassar. http://repository.unhas.ac.id/JURNAL/Raml ah. Diakses tanggal 28 Juni 2018.

Harnisah1, Slamet Riyadi2, dan Fitra Mulia Jaya2, Karakteristik Dendeng Ikan Nila (Oreochromis niloticus) Dengan Konsentrasi Penambahan Gula Aren Berbeda, Jurnal Ilmu-Ilmu Perikanan dan Budidaya Perairan Volume 13, Nomor 2, Desember 2018

Sugih Barokah Muhamad, Eddy Afrianto, dan Nia Kurniawati, Foritifikasi Daging Nila Terhadap Karakteristik Organoleptik Dan Kimia Kecimpring, Jurnal Perikanan dan Kelautan Vol. VIII No. 1/Juni 2017 (174178) 